\title{
Applying the Theory of Planned Behaviour (TPB) in Saving Behaviour of Pomak Households
}

\author{
Nikolaos Satsios $^{1} \&$ Spyros Hadjidakis ${ }^{1}$ \\ ${ }^{1}$ Department of Finance and Economics, University of Nicosia, Nicosia, Cyprus \\ Correspondence: Nikolaos Satsios, Department of Finance and Economics, School of Business, University of \\ Nicosia, Nicosia, Cyprus.
}

Received: February 8, 2018

Accepted: March 10, $2018 \quad$ Online Published: March 16, 2018

doi:10.5430/ijfr.v9n2p122

URL: https://doi.org/10.5430/ijfr.v9n2p122

\begin{abstract}
The following study uses the Ajzen's Theory of Planned Behaviour as a theoretical framework with the purpose of extending a model which examines the saving behaviour of the Pomak households. The aim of this research is to identify factors that influence the saving behaviour of Pomak households in Greece. For the collection of data from households, a structured questionnaire was designed and distributed. The data of the study were obtained from a survey applied in 600 households in the prefectures of Xanthi, Rodopi and Evros. A path analysis was applied in order to confirm the proposed model and the results of the hypothesis tested. Findings show that attitude, subjective norm and perceived behavioural control have a direct positive effect on intention towards saving and final saving behaviour. The understanding of the Pomaks' saving behaviour can have a significant contribution in the pursuit of a healthy household's financial life.
\end{abstract}

Keywords: saving behaviour, pomaks, TPB theory

\section{Introduction}

Saving can be considered the result of a decision-making process and to save as the act of regularly setting aside resources for a goal (Lewis et al., 1995; Warneryd, 1999). Household saving is essential because it affects a family's level of living, emergency reserves, and the ability to meet financial goals and expectations (Anong \& DeVaney, 2010; Hira, 1987; Lee et al., 2000). Since, savings by families flow into financial institutions and that assets are essential for their own functioning as organizations that support the economy, it is clear that decisions upon saving made by households have a powerful effect on the economic performance.

The wealth of minority groups today is important in considering the wealth of country households in the future (Hanna \& Lindamood, 2008). The society in the region of Thrace in Greece is multicultural. Thrace is acknowledged as a canvas depicting interesting social, cultural and religious aspects of a community which is consisted of Christians, Pomaks (Muslims), Turkish and Roma citizens. The Pomaks is a religious minority, approximately 36.000 settled in Greece and more specifically, 23.000 in the Prefecture of Xanthi, 11.000 in the Prefecture of Rodopi and 2.000 in the Prefecture of Evros (ELSTAT, 2011). A diverse religious environment may drive to different cultures, values, and norms, and may negative affect saving cost.

This study focused on saving behaviour of Pomak households, with particular emphasis on the relationship among attitude, subjective norm, perceived behavioural control and intention on the final saving behaviour of them. To achieve this goal, SEM techniques were applied in the light of evaluating and estimating the reliability and validity of the TPB scenario through the medium of confirmatory factor analysis. The above approach enabled the identification of some issues in order to evaluate the TPB constructs.

\section{Theoretical Framework}

The Theory of Planned Behaviour provides a useful conceptual framework for dealing with the complexities of human social behaviour (Ajzen, 1991) and is frequently used to explain behavioural patterns and better understand how individuals make behavioural decisions (Xiao \& Wu, 2008). Ajzen indicated that the precedent of any behaviour is the formation of an intention towards that behaviour. TPB is applied in order to investigate the deeper beliefs that influence a person's financial behaviour (Zocchi, 2013). Consequently, it is vital that strategies be researched and designed to help individuals in adopting positive financial behaviours. Generally, individuals are 
motivated to save (Abrahamse \& Steg, 2009; Karlsson et al., 2004). Nevertheless, a participant's capability to save was influenced by the lack of opportunity, lack of knowledge, lack of willpower, and their attitudes toward savings and financial institutions (Abrahamse \& Steg, 2009; Karlsson et al., 2004). The TPB has constantly been applied in the social psychology literature and has been applied to investigations in the field of credit counselling, personal finance and private money management both domestically and internationally (Ajzen, 1991; Bobek et al., 2007; Francis et al., 2004; Kidwell \& Turrisi, 2004; Ramayah et al., 2009; Rutherford \& DeVaney, 2009; Xiao \& Wu, 2008). Financial knowledge or literacy has been found to be positively associated with improved financial behaviours, including higher rates of savings (Huston et al., 2012; Lusardi et al., 2010; Lyons et al., 2006). The usage TPB based models on financial and saving behaviour displayed positive results, with $51 \%$ financial budget, keeping (Kidwell \& Turrisi, 2004) to $72 \%$ retirement saving (Croy et al., 2010) of the variance in intention. The model interpreted $41 \%$ of variance in self-reported saving deposits (Loibl et al., 2011) and further anticipates negative economic behaviours (e.g., not paying bills, using payday loans) (Xiao et al., 2011). This study will reveal if attitude, subjective norm and perceived behavioural control will have a correlation and interconnection between them with saving behaviour. The direct positive relationship of attitude, subjective norm and perceived behavioural control underlined in studies conducted by Ajzen (1991; 2002), Benk et al. (2011), Dowd \& Burke (2013), Faye et al. (2013), Jen-Ruei et al. (2006), Litvine \& Wüstenhagen (2011), Minton et al. (2015), Taylor \& Todd (1995), Tsourgiannis et al. (2014), Zocchi (2013).

\section{Research Model and Hypotheses}

The model of TPB in this study was applied to explore the extent to which attitude (ATT), subjective norm (SN) and perceived behavioural control (PBC) influence Pomak households' intention (INT) to saving. The conceptual model is presented in Figure 1:

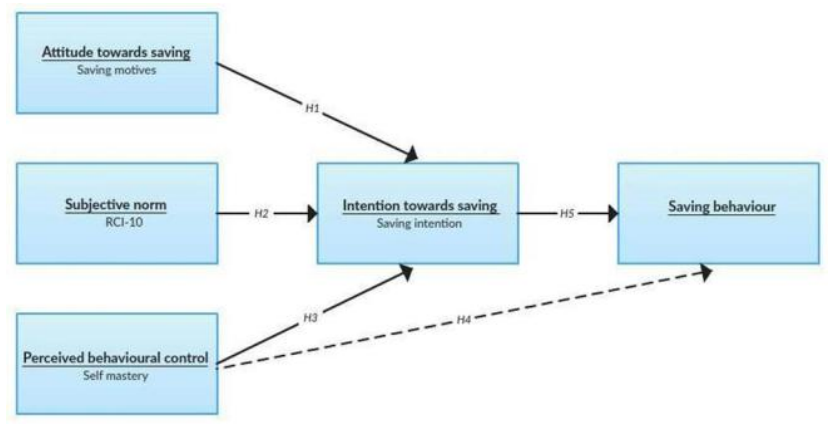

Figure 1. The conceptual framework

Attitudes towards saving are supposed to be potent associated and rooted with upbringing and lifestyle. In a similar case, both Keynes (1936) and Katona (1975) claimed that most persons have positive attitudes towards saving. Generally, while most individuals are positive towards saving, they might vary in their attitudes towards concrete acts of saving and on private saving. Many studies have found the significant effect of attitudes on intention (Ing-Long \& Jian-Liang, 2005; Lu et al., 2003; Ramayah et al., 2003; 2009; Rhodes \& Courneya, 2003; Taylor \& Todd, 1995) and that a behavioural intention reflects a person's decision to perform the behaviour (Ajzen, 1991). Consequently, attitude can be regarded as an essential part of predicting and describing human behaviour (Ajzen, 1987). Therefore, the next hypothesis is proposed:

H1: There is a significant and positive relationship between attitude and intention toward saving.

Ajzen \& Driver (1992) proposed that the subjective norm can predict behavioural intention. It is the most significant predictive factor of behavioural intention (Tsai, 2010). Subjective norms of individuals can affect behavioural intention (Bock \& Kim, 2002; Kuo \& Young, 2008). Moreover, as subjective norm becomes more positive, behavioural intention to participation also becomes more positive (Kuo \& Dai, 2012). Further, studies have shown no significant relationship between SN and intention (Chau \& Hu, 2001; Lewis et al., 2003) whereas other studies depict the opposing outcome (Chan \& Lu, 2004; Jen-Ruei et al., 2006; Ramayah et al., 2004; Taylor \& Todd, 1995; Venkatesh \& Davis, 2000). It is with these findings that this study states the subsequent hypothesis:

H2: There is a significant and positive relationship between subjective norm and intention towards saving. 
Ajzen (1985) identified perceived control behaviour as influencing behavioural intention and directly influencing actual behaviour. Perceived behavioural control have an important contribution in predicting behavioural intention and have a greater influence than attitude (Hsu \& Huang, 2012). Between the factors affecting the behavioural intention of individuals towards participation, the current construct, has the most impact (Yang, 2013). As the PBC of an individual gets more positive, the behavioural intention to participate also transforms as a more positive (Kuo \& Young, 2008). Godin et al. (2005) stated that perceived behavioural control can increase the explained variance towards behavioural intention. As a result, the following research hypotheses have been constructed:

H3: There is a significant and positive relationship between perceived behavioural control and intention towards saving.

H4: There is a significant and positive relationship between perceived behavioural control and final saving behaviour.

Intention is a basic construct of the TPB and it is supposed to directly affect a given behaviour because it is an indication of how willing individuals are to perform the action (Ajzen, 1991; Armitage \& Conner, 2001). According to the TPB, the amount of volitional control specifies, to what degree intentions are transformed into behaviour (Ajzen, 1991; Armitage \& Conner, 2001). A behaviour such as saving money is not under full volitional control, because the availability of opportunities and resources affects the competence to execute the behaviour (Ajzen, 1991). Further, individuals with bigger incomes save more (Davis \& Hustvedt, 2012; Hershey et al., 2008; Lusardi, 2008). In contrast, perceptions of barriers affect saving behaviour of persons who believe that they have not much money for saving and make them unwilling (Lusardi et al., 2009). Hence, the hypothesis is:

H5: There is a significant and positive relationship between intention towards saving and final saving behaviour.

\section{Method}

\subsection{Sample and Procedure}

The survey was given to 600 respondents in Greece and specifically in the region of Thrace in three different prefectures of Xanthi, Rodopi and Evros from April to October 2016. The self-completion questionnaire was administered face to face in several physical locations in this region and analyse to the respondents the aim of the nature of research. The sample included 190 women and 410 men. The adult head of the household was questioned in order to retrieve information for the household. Households in the survey were selected through the snowball sampling procedure. Respondents of different ages, genders, educational levels and marital status were chosen. The data collection process was accurate and careful.

\subsection{Measures}

All items intended to measure the variables in this study were adopted from previously validated instruments (Table 1).

Table 1. List of items and their sources

\begin{tabular}{|c|c|c|}
\hline Constructs & Items & Abbrev. \\
\hline $\begin{array}{l}\text { Attitude towards Saving } \\
\text { (adapted from DeVaney et } \\
\text { al., 2007, Saving motives } \\
\text { hierarchy) }\end{array}$ & $\begin{array}{l}\text { Paying debts } \\
\text { Retirement } \\
\text { Education / love / family } \\
\text { Future uncertainties / emergency / safety }\end{array}$ & $\begin{array}{l}\text { ATT1 } \\
\text { ATT2 } \\
\text { ATT3 } \\
\text { ATT4 }\end{array}$ \\
\hline $\begin{array}{l}\text { Subjective Norms } \\
\text { (adapted from Worthington } \\
\text { et al., 2003; 2012, RCI-10 } \\
\text { scale) }\end{array}$ & $\begin{array}{l}\text { I make financial contributions to my religious organization. } \\
\text { I spend time trying to grow in understanding of my faith. } \\
\text { Religion is especially important to me because it answers many questions about } \\
\text { the meaning of life. } \\
\text { My religious beliefs lie behind my whole approach to life. }\end{array}$ & $\begin{array}{l}\text { SN1 } \\
\text { SN2 } \\
\text { SN3 } \\
\text { SN4 }\end{array}$ \\
\hline $\begin{array}{l}\text { Perceived } \quad \text { Behavioural } \\
\text { Control } \\
\text { (adapted from Pearlin \& } \\
\text { Schooler's, } \quad 1978, \\
\text { Self-Mastery scale) }\end{array}$ & $\begin{array}{l}\text { There is really no way I can solve some of the problems I have. } \\
\text { Sometimes I feel that I'm being pushed around in life. } \\
\text { I have little control over the things that happen to me. } \\
\text { I often feel helpless in dealing with the problems of life. } \\
\text { There is little I can do to change many of the important things in my life. }\end{array}$ & $\begin{array}{l}\text { PBC1 } \\
\text { PBC2 } \\
\text { PBC3 } \\
\text { PBC4 } \\
\text { PBC5 }\end{array}$ \\
\hline $\begin{array}{l}\text { Intention towards Saving } \\
\text { (adapted from Warneryd, } \\
\text { 1996a; 1996b, Twenty-One } \\
\text { saving items scale) }\end{array}$ & $\begin{array}{l}\text { I always try to pick saving schemes that yield high profits. } \\
\text { It is important always to save as much money as possible. } \\
\text { It is important to have some money left at the end of the month. } \\
\text { Saving should be encouraged in today's society. }\end{array}$ & $\begin{array}{l}\text { INT1 } \\
\text { INT2 } \\
\text { INT3 } \\
\text { INT4 }\end{array}$ \\
\hline
\end{tabular}




\subsection{Reliability}

Cronbach's alpha was calculated for all the scales of the questionnaire (Table 2). For all academic scales that was used the internal reliability was good or very good.

Table 2. Cronbach's alpha of final survey

\begin{tabular}{lll}
\hline Scale & Pilot survey Cronbach's a (N=600) & N (Items) \\
\hline ATT &, 714 & 4 \\
SN &, 784 & 4 \\
PBC &, 700 & 5 \\
INT &, 730 & 4 \\
\hline
\end{tabular}

\subsection{Principal Component Analysis}

Principal components analysis was applied, regarding to confirm factor structure of the structure participated in TPB model. The method was applied for each one part of the survey in order to confirm the univariate nature of the primary constructs as well as for the total questionnaire to confirm that the four constructs are separated.

The Kaiser-Meyer-Olkin measure of sampling adequacy indicated that the sample was adequate (Table 3), to perform principal components analysis.

Table 3. Kaiser-Meyer-Olkin

\begin{tabular}{ll}
\hline Structure & Kaiser-Meyer-Olkin, Measure of Sampling Adequacy \\
\hline ATT & 0,751 \\
SN & 0,765 \\
PBC & 0,778 \\
INT & 0,764 \\
\hline
\end{tabular}

Additionally, the structures were positively correlated thus appropriate for participating in the path model (Table 4).

Table 4. Pearson correlation coefficients

\begin{tabular}{llll}
\hline & ATT & SN & PBC \\
\hline SN &, $245^{* *}$ & & \\
PBC &,$- 064^{* *}$ &,$- 225^{* *}$ & \\
INT &, $364^{* *}$ &, $464^{* *}$ &,$- 238^{* *}$ \\
\hline
\end{tabular}

**. Correlation is significant at the 0.01 level (2-tailed).

The results of the PCA confirmed the one-factor solution for all the constructs that was selected to participate in the TPB model (

Table 5).

Table 5. Eigenvalues from PCA

\begin{tabular}{lll}
\hline Structure & Eigenvalue of the first component & \% of the explained variance \\
\hline ATT & 2,167 & 54,166 \\
SN & 2,442 & 61,049 \\
PBC & 2,274 & 45,486 \\
INT & 2,213 & 55,335 \\
\hline
\end{tabular}


Moreover, the application of the method for all questionnaire items suggested a four components solution explaining $54,6 \%$ of the total variance (Table 6). Thus, the desired structure was confirmed and the questionnaire was proved to be adequate for the research purpose.

Table 6. Rotated component matrix

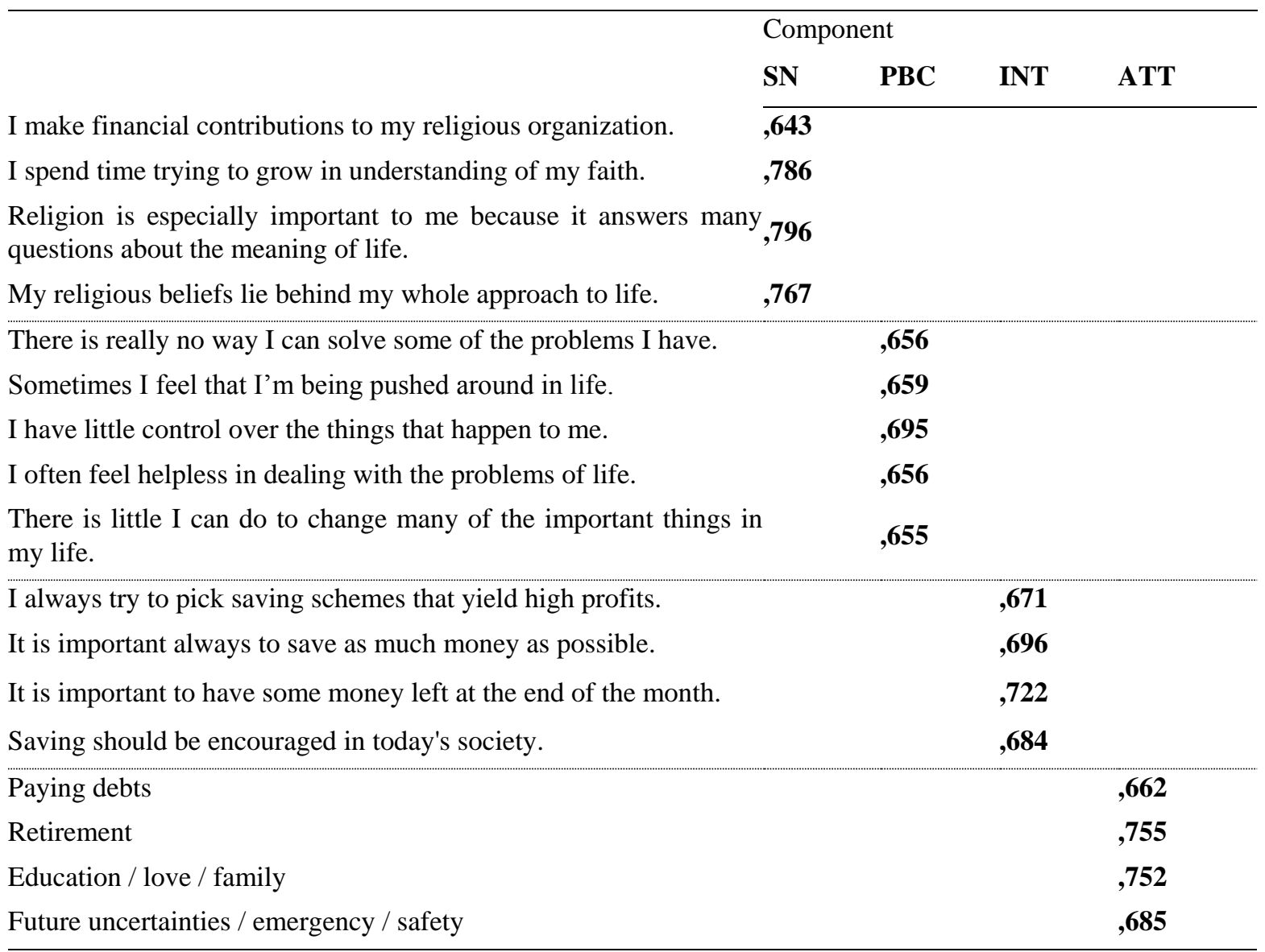

Extraction Method: Principal Component Analysis.

Rotation Method: Varimax with Kaiser Normalization.

a. Rotation converged in 5 iterations.

\subsection{Confirmatory Factor Analysis}

Structural equation modelling was applied in order to confirm the structure that was suggested from the principal components analysis (Figure 2). All 600 observations were used in order to estimate the coefficients. The model was converged after 37 iterations. The model was statistical significant $\left(c^{2}(136)=2501.260, p<0.001\right)$. The model was well fitted to the data $(\mathrm{CFI}=0.949$, TLI $=0.938$, RMSEA $=0.042,90 \%$ C.I. $0.035-0.050$, SRMR $=0.046, \mathrm{NFI}=$ $0.906, \mathrm{NNFI}=0.938$ ).

The results of composite reliability (CR) for all constructs exceeded the 0.7 and the average variance extracted (AVE) were closely on the recommended level 0.5 . Consequently, these results indicated that the convergent validity for all constructs was adequate (see Table 7). 
Table 7. Average variance extracted (AVE) and composite reliability (CR)

\begin{tabular}{ccc}
\hline Construct & AVE & CR \\
\hline ATT & 0,51 & 0,81 \\
SN & 0,56 & 0,84 \\
PBC & 0,44 & 0,80 \\
INT & 0,48 & 0,79 \\
\hline
\end{tabular}

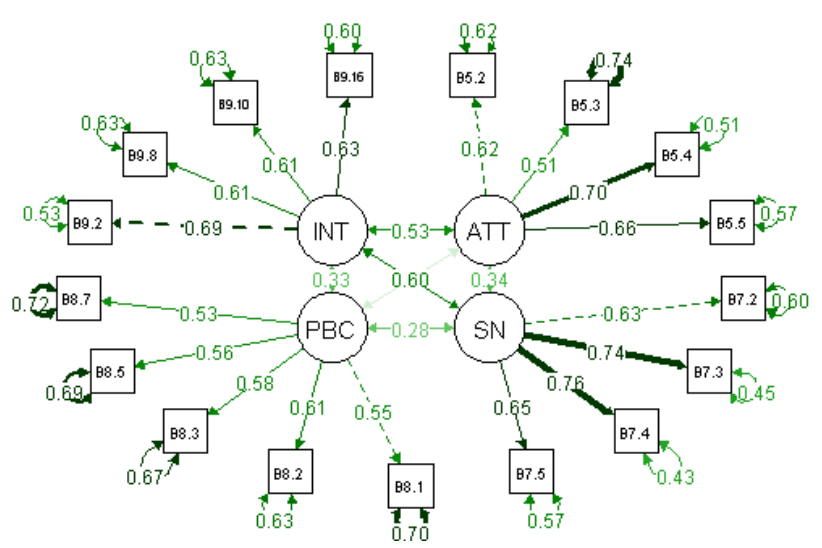

Figure 2. Confirmatory factor analysis

\section{Path Analysis}

The hypothetical model was assumed to be the model suggested by the theory. All 600 observations were used in order to estimate the coefficients. The model was converged after 57 iterations (Table 8). Chi square test $\left(\mathrm{c}^{2}(2)=\right.$ $0.954, \mathrm{p}=0.621$ ) implies that the assumed model is adequate for the data, that is, the model and the data are not statistically significantly different. The model was statistical significant $\left(\mathrm{c}^{2}(10)=280.661, \mathrm{p}<0.001\right)$. The model was well fitted to the data $(\mathrm{CFI}=1.000, \mathrm{TLI}=1.000, \mathrm{RMSEA}=0,90 \%$ C.I. $0-0.065$, SRMR $=0.009, \mathrm{NFI}=0.997$, $\mathrm{NNFI}=1.00, \mathrm{GFI}=0.999, \mathrm{AGFI}=0.995)$.

The standardized regression coefficients are presented in Figure 3, while the covariance matrix is presented at Table 9.

Table 8. First path model's parameters

\begin{tabular}{cccccccccc}
\hline & Estimate & $\begin{array}{c}\text { 95\% C.I. } \\
\text { Lower }\end{array}$ & Upper & Std. Err & z-value & $\mathbf{p}$ & $\begin{array}{c}\text { Std. } \\
\mathbf{1 v}^{*}\end{array}$ & $\begin{array}{c}\text { Std. } \\
\text { all }^{* *}\end{array}$ & $\mathbf{R}^{\mathbf{2}}$ \\
\hline INT & & & & & & & & & 0.290 \\
ATT & 0.528 & 0.402 & 0.654 & 0.064 & 8.216 & 0.000 & 0.528 & 0.289 & \\
SN & 0.339 & 0.269 & 0.408 & 0.035 & 9.564 & 0.000 & 0.339 & 0.346 & \\
PBC & 0.315 & 0.150 & 0.480 & 0.084 & 3.744 & 0.000 & 0.315 & 0.133 & \\
\hline SB & & & & & & & & & 0.018 \\
INT & 0.037 & 0.013 & 0.061 & 0.012 & 3.022 & 0.003 & 0.037 & 0.126 & \\
PBC & -0.059 & -0.116 & -0.003 & 0.029 & -2.050 & 0.040 & -0.059 & -0.085 & \\
\hline
\end{tabular}

Note: $\mathrm{c}^{2}(10)=280.661, \mathrm{p}<0.001 ;$ RMSEA $=0, \mathrm{NFI}=0.997, \mathrm{CFI}=1.000, \mathrm{TLI}=1.000$.

(*) Dependent Variables are standardized.

(**) Completely standardized solution (estimates of parameters if the variances of the observed and latent variables are unity). 
Table 9. Path covariance matrix

\begin{tabular}{lcccccc}
\hline & Estimate & Std.Err & z-value & $\mathbf{P}(>|\mathbf{z}|)$ & Std.lv & Std.all \\
\hline ATT & & & & & & \\
SN & 5.685 & 1.124 & 5.060 & 0.000 & 5.685 & 0.211 \\
PBC & 0.715 & 0.454 & 1.575 & 0.115 & 0.715 & 0.064 \\
\hline SN & & & & & & \\
PBC & 4.977 & 0.870 & 5.720 & 0.000 & 4.977 & 0.240 \\
\hline
\end{tabular}

The direct and indirect effects of the constructs on saving behaviour are presented in Table 10. Attitude towards saving (ATT) had a significant positive direct effect on intention towards saving (INT) $\left(b_{\text {std }}=0.289, b=0.528,95 \%\right.$ C.I. $=$ 0.402 to $0.654, \mathrm{p}<0.001)$ and a significant positive indirect effect on saving behaviour $(\mathrm{SB})\left(\mathrm{b}_{\mathrm{std}}=0.036, \mathrm{~b}=0.019, \mathrm{p}\right.$ $=0.005)$. Subjective norm $(\mathrm{SN})$ had a significant positive direct effect on intention towards saving $($ INT $)\left(b_{\text {std }}=0.346\right.$, $\mathrm{b}=0.339,95 \%$ C.I. $=0.269$ to $0.408, \mathrm{p}<0.001)$ and a significant positive indirect effect on saving behaviour $(\mathrm{SB})\left(\mathrm{b}_{\mathrm{std}}\right.$ $=0.044, \mathrm{~b}=0.012, \mathrm{p}=0.004)$. On the other hand, intention (INT) had a significant positive direct effect on saving behaviour $(\mathrm{SB})\left(\mathrm{b}_{\mathrm{std}}=0.126, \mathrm{~b}=0.037,95 \%\right.$ C.I. $=0.013$ to $\left.0.061, \mathrm{p}=0.003\right)$. Finally, perceived behavioural control (PBC) had a significant positive direct effect on intention towards saving (INT) $\left(b_{\text {std }}=0.133, b=0.315,95 \%\right.$ C.I. 0.150 to $0.480, \mathrm{p}<0.001)$, a negative direct effect on saving behaviour $(\mathrm{SB})\left(\mathrm{b}_{\mathrm{std}}=-0.085, \mathrm{~b}=-0.059,95 \%\right.$ C.I. $=$ -0.116 to $-0.003, \mathrm{p}=0.04)$ and a significant positive indirect effect on saving behaviour $(\mathrm{SB})\left(\mathrm{b}_{\mathrm{std}}=0.017, \mathrm{~b}=0.012, \mathrm{p}\right.$ $=0.019)$.

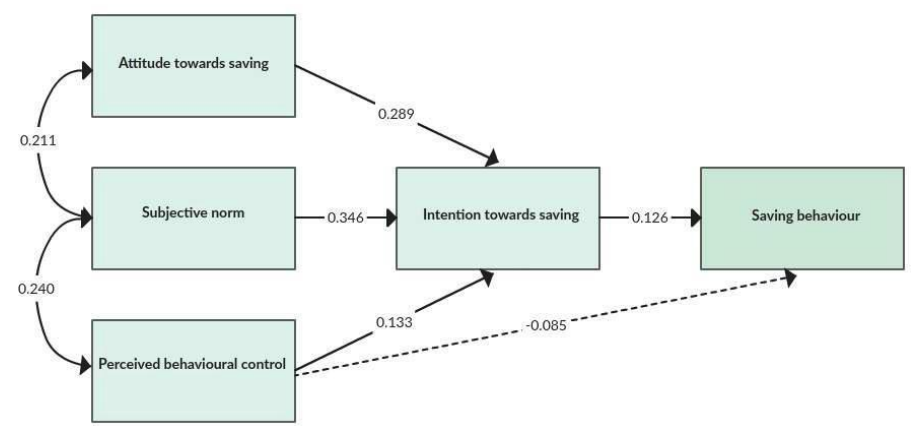

Figure 3. Path analysis results on the effect of attitude towards saving, subjective norm and perceived behavioural control on intention towards saving and saving behaviour (standardized estimates, $\mathrm{N}=600$ )

Table 10. Summary of path model

\begin{tabular}{llll}
\hline Path $/$ Effect & Direct effect & Indirect effect & Total effect \\
\hline ATT $\rightarrow$ INT & 0.289 & & 0.289 \\
ATT $\rightarrow$ SB & & 0.036 & 0.036 \\
SN $\rightarrow$ INT & 0.346 & & 0.346 \\
SN $\rightarrow$ SB & & 0.044 & 0.044 \\
PBC $\rightarrow$ INT & 0.133 & & 0.133 \\
PBC $\rightarrow$ SB & -0.085 & 0.017 & $-0,068$ \\
INT $\rightarrow$ SB & 0.126 & & 0.126 \\
\hline
\end{tabular}

\section{Discussion}

The study showed that attitude had a significant and positive effect on saving behaviour of the Pomaks households, a hypothesis that was suggested by various authors in the literature (Ing-Long \& Jian-Liang, 2005; Lu et al., 2003; 
Ramayah et al., 2003; 2009; Rhodes \& Courneya, 2003; Taylor \& Todd, 1995). In particular, the households' heads with higher positive attitudes founded to have a greater intention to save. This finding agrees with previous studies (Choo et al., 2004; Fisher \& Montalto, 2010; Lea et al., 1995; Warneryd, 1999; Webley \& Nyhus, 2001) which supported the TPB theory concerns of attitude as predictor of intention towards saving.

It was found that subjective norm was the strongest predictor of intention and had a significant indirect effect on saving behaviour (Ajzen \& Driver, 1992; Bock \& Kim, 2002; Chan \& Lu, 2004; Jen-Ruei et al., 2006; Kuo \& Young, 2008; Taylor \& Todd, 1995; Tsai, 2010; Venkatesh \& Davis, 2000). This means that households with influential beliefs were more likely to produce favourable intention towards saving and transform the intention into action. That result was confirmed by previous studies (Arrunada, 2010; Belzen, 1999; Guiso et al., 2003; Karijin et al., 2007; McCleary, 2007; Mokhlis, 2009; Renneboog \& Spaenjers, 2012).

In contrast with the previous constructs of TPB, the results concerning the perceived behavioural control indicated a positive statistically effect on intention towards saving, while it provided a direct negative effect on saving behaviour. The correlation between PBC and intention is positive, which means that the effect of self-control in explaining variability in behaviour is not rare. This is related to previous researches (Gopi \& Ramayah, 2007; Ing-Long \& Jian-Liang, 2005; Jen-Ruei et al., 2006; Lee, 2009; Taylor \& Todd, 1995). However, Ryu et al. (2003) and Albarracin et al. (2001) demonstrate that the influence of PBC on intention towards saving, is moderate. In particular, the findings on the direct effect of intention on final saving behaviour were negative, which means that as self-mastery is increased, the final actual saving behaviour is reduced.

In current path model, the intention had a significant positive direct effect on saving behaviour (Ajzen, 1991; Armitage \& Conner, 2001; Davis \& Hustvedt, 2012; Hershey et al., 2008; Lusardi, 2008). As a result, the intention to save depicts an important process to final saving behaviour (Ruefenacht et al., 2015). In several TPB studies, behavioural intention is considered as a proxy measure of likely behaviour (e.g., Phillips \& Jang, 2012; Sparks \& Pan, 2009; Wang \& Ritchie, 2013).

\subsection{Implication of the Findings}

In this study, the proposed framework model provides emphasis upon how the saving behaviour is influenced by the elements of TPB model, with the purpose of understanding the Pomak households' saving behaviour. The current results enhance the comprehensive of the relationship between Pomaks' characteristics and their effect on the intention towards saving. Furthermore, these findings will help banks to gain better understanding of the saving behaviour among Pomak households and enlighten them to create new opportunities for considering this minority group as part of their valuable customers. In particular, they can promote financial products or services according to their needs and preferences.

\subsection{Directions of Future Research}

This study was limited to Pomak households in Thrace (Greece) but there are Pomak populations in Bulgaria area as well. To improve the generalized ability of future findings, future studies could expand in order to include a sample of the neighbouring country. Therefore it suggests that the TPB conceptual, theoretical framework should be empirically validated in other regions of the world and the findings being compared to these ones. A more global, holistic understanding of minority population's attitudes, views and intention towards saving on saving behaviour can emerge. Deeper investigation is required for testing of TPB in Western and Muslim nations.

\section{References}

Abrahamse, W., \& Steg, L. (2009). How do socio-demographic and psychological factors relate to households' direct and indirect energy use and savings?. Journal of Economic Psychology, 30, 711-720. https://doi.org/10.1016/j.joep.2009.05.006

Ajzen, I., \& Driver, B. L. (1992). Application of the theory of planned behaviour to leisure choice. Journal Leisure Res, 24(3), 207-224. https://doi.org/10.1080/00222216.1992.11969889

Ajzen, I. (1985). From intentions to actions: A theory of planned behaviour. In Kuhl, J. \& Beckman, J. (Eds.), Action-control: From cognition to behaviour (pp. 11-39). Heidelberg: Springer. https://doi.org/10.1007/978-3-642-69746-3_2

Ajzen, I. (1987). Attitudes, traits, and actions: Dispositional prediction of behaviour in personality and social psychology. In Berkowitz, L. (Ed.), Advances in experimental social psychology (Vol. 20, pp. 1-63). New York: Academic Press. https://doi.org/10.1016/S0065-2601(08)60411-6 
Ajzen, I. (1991). The theory of planned behaviour. Organizational behaviour and human decision processes, 50, 179-211. https://doi.org/10.1016/0749-5978(91)90020-T

Ajzen, I. (2002). Perceived behavioural control, self-efficacy, locus of control, and the theory of planned behaviour. Journal of Applied Social Psychology, 32(4), 665-683. https://doi.org/10.1111/j.1559-1816.2002.tb00236.x

Albarracin, D., Johnson, B. T., Fishbein, M., \& Muellerleile, P. A. (2001), Theories of reasoned action and planned behaviour as models of condom use: A meta-analysis. Psychological Bulletin, 127, 142-161. https://doi.org/10.1037/0033-2909.127.1.142

Anong, S. T., \& DeVaney, S. A. (2010). Determinants of adequate emergency funds including the effects of seeking professional advice and industry affiliation. Family and Consumer Sciences Research Journal, 38(4), 405-419. https://doi.org/10.1111/j.1552-3934.2010.00035.x

Armitage, C., \& Conner, M. (2001). Efficacy of the theory of planned behaviour: A meta analytic review. British Journal of Social Psychology, 40, 471-499. https://doi.org/10.1348/014466601164939

Arrunada, B. (2010). Protestants and Catholics: Similar work ethic, different social ethic. Economic Journal, 120, 890-918. https://doi.org/10.1111/j.1468-0297.2009.02325.x

Belzen, J. A. (1999). The cultural psychological approach to religion: contemporary debates on the object of the discipline. Theory \& Psychology, 9(2), 229-255. https://doi.org/10.1177/095935439992004

Benk, S., Çakmak, A. F., \& Budak, T. (2011). An investigation of tax compliance intention: A theory of planned behavior approach. European Journal of Economics, Finance and Administrative Sciences, 28, 181-188.

Bobek, D. D., Hatfield, R. C., \& Wentzel, K. (2007). An investigation of why taxpayers prefer refunds: A theory of planning behaviour approach. Journal of the American Taxation Association, 29(1), 93-111. https://doi.org/10.1521/jata.2007.29.1.93

Bock, G. W., \& Kim, Y. G. (2002). Breaking the myths of rewards: an exploratory study of attitudes about knowledge sharing. Information Resources Management Journal, 15(2), 14-21. https://doi.org/10.4018/irmj.2002040102

Chan, S. C., \& Lu, M. T. (2004). Understanding internet banking adoption and user behaviour: a Hong Kong perspective. Journal of Global Information Management, 12(3), 21-43. https://doi.org/10.4018/jgim.2004070102

Chau, P. Y., \& Hu, P. J. (2001). Information technology acceptance by individual professionals: a model comparison approach. Decision Science, 32(4), 699-719. https://doi.org/10.1111/j.1540-5915.2001.tb00978.x

Choo, H., Chung, J. E., \& Pysarchik, D. T. (2004). Antecedents to new food product purchasing behaviour among innovator groups in India. European Journal of Marketing, 38(5), 608-625. https://doi.org/10.1108/03090560410529240

Croy, G., Gerrans, P., \& Speelman, C. (2010). The role and relevance of domain knowledge, perceptions of planning importance and risk tolerance in predicting savings intentions. Journal of Economic Psychology, 31(6), 860-871. https://doi.org/10.1016/j.joep.2010.06.002

Davis, K., \& Hustvedt, G. (2012). It's a matter of control: Saving for retirement. International Review of Social Sciences and Humanities, 3(2), 248-261.

DeVaney, S. A., Anong, S. T., \& Whirl, S. E. (2007). Household savings motives. Journal of Consumer Affairs, 4l(1), 174-186. https://doi.org/10.1111/j.1745-6606.2006.00073.x

Dowd, K., \& Burke, K. (2013). The influence of ethical values and food choice motivations on intentions to purchase sustainably sourced foods. Elsiever, Appetite, 69, 137-144. https://doi.org/10.1016/j.appet.2013.05.024

ELSTAT. (2011). Census 2011. Retrieved March 19, 2015, from http://www.statistics.gr/portal/page/portal/ESYE/PAGE-themes?p_param=A1602

Faye, I., Triki, T., \& Kangoye, T. (2013). The Islamic finance promises: Evidence from Africa. Review of Development Finance, 3, 136-151. https://doi.org/10.1016/j.rdf.2013.08.003

Fisher P. J., \& Montalto, C. P. (2010). Effect of saving motives and horizon on saving behaviours. Journal of Economic Psychology, 31(1), 92-105. https://doi.org/10.1016/j.joep.2009.11.002 
Francis, J., Eccles, M. P., Johnston, M., Walker, A. E., Grimshaw, J. M., Foy, R., ... Bonetti, D. (2004). Constructing questionnaires based on the Theory of Planned behaviour: A manual for health services researchers, Newcastle upon Tyne, UK: Centre for Health Services Research, University of Newcastle upon Tyne, ISBN-10: 0954016157.

Godin, G., Conner, M., \& Sheeran, P. (2005). Bridging the intention-behaviour 'gap': The role of moral norm. British Journal of Social Psychology, 44, 497-512. https://doi.org/10.1348/014466604X17452

Gopi, M., \& Ramayah, T. (2007). Applicability of theory of planned behaviour in predicting intention to trade online: Some evidence from a developing country. International Journal of Emerging Markets, 2(4), 348-360. https://doi.org/10.1108/17468800710824509

Guiso, L., Sapienza, P., \& Zingales, L. (2003). People's opium? Religion and economic attitudes. Journal of Monetary Economics, 50(1), 225-282. https://doi.org/10.1016/S0304-3932(02)00202-7

Hanna, S. D., \& Lindamood, S. (2008). The decrease in stock ownership by minority households. Journal of Financial Counseling and Planning, 19, 46-58.

Hershey, D., Jacobs-Lawson, J. M., McArdle, J. J., \& Hamagami, F. (2008). Psychological foundations of financial planning for retirement. Journal of Adult Development, 14(1-2), 26-36. https://doi.org/10.1007/s10804-007-9028-1

Hira, T. (1987). Households' financial management factors influencing solvency and satisfaction. The Journal of Japan Society of Household Economics, 10, 199-210.

Hsu, C. H. C., \& Huang, S. (2012). An extension of the theory of planned behaviour model for tourists. Journal of Hospitality \& Tourism Research, 36(3), 390-417. https://doi.org/10.1177/1096348010390817

Huston, S., Finke, M. S., \& Smith, H. (2012). A financial sophistication proxy for the Survey of consumer finances. Applied Economics Letters, 19(13), 1275-1278. https://doi.org/10.1080/13504851.2011.619485

Ing-Long, W., \& Jian-Liang, C. (2005). An extension of Trust and TAM model with TPB in the initial adoption of on-line tax: An empirical study. International Journal of Human-Computer Studies, 62(6), 784-808. https://doi.org/10.1016/j.ijhcs.2005.03.003

Jen-Ruei, F., Cheng-Kiang, F., \& Wen-Pin, C. (2006). Acceptance of electronic tax filing: a study of taxpayer intentions. Information \& Management, 43, 109-126. https://doi.org/10.1016/j.im.2005.04.001

Karijin, B., Iris, V., Florence, B. B., \& Wim, V. (2007). Determinants of halal meat consumption in France. British Food Journal, 109(5), 367-386. https://doi.org/10.1108/0070700710746786

Karlsson, N., Dellgran, P., Klingander, B., \& Garling, T. (2004). Household consumption: Influences of aspiration level, social comparison, and money management. Journal of Economic Psychology, 25, 753-769. https://doi.org/10.1016/j.joep.2003.07.003

Katona, G. (1975). Psychological economics. New York: Elsevier.

Keynes, J. M. (1936). The general theory of employment interest and money, pp. 1-472. London: Macmillan Press Ltd.

Kidwell, B., \& Turrisi, R. (2004). An examination of college student money management tendencies. Journal of Economic Psychology, 25(5), 601-616. https://doi.org/10.1016/S0167-4870(03)00073-4

Kuo, F. Y., \& Young, M. L. (2008). Predicting knowledge sharing practices through intention: A test of competing models. Computers in Human Behavior, 24, 2697-2722. https://doi.org/10.1016/j.chb.2008.03.015

Kuo, N. W., \& Dai, Y. Y. (2012). Applying the Theory of Planned Behaviour to predict low-carbon tourism behaviour: A modified model from Taiwan. International Journal of Technology and Human Interaction (IJTHI), 8(4), 45-62. https://doi.org/10.4018/jthi.2012100103

Lea, S. E. G., Webley, P., \& Walker, C. M. (1995). Psychological factors in consumer debt: money management, time horizons and consumer behaviour. Journal of Economic Psychology, 16, 681-701. https://doi.org/10.1016/0167-4870(95)00013-4

Lee, M. C. (2009). Factors influencing the adoption of internet banking: An integration of TAM and TPB with perceived risk and perceived benefit. Electronic Commerce Research and Applications, 8(3), 130-141. https://doi.org/10.1016/j.elerap.2008.11.006 
Lee, S. L., Park, M. H., \& Montalto, C. P. (2000). The effect of family Life Cycle and financial management practices on household saving patterns. International Journal of Human Ecology, 1(1), 79-93.

Lewis, A., Webley, P., \& Furnham, A. (1995). The new economic mind. The social psychology of economic behaviour $\left(2^{\text {nd }}\right.$ ed.). Hemel Hempstead: Harvester Wheat sheaf.

Lewis, W. A. (2003). The Theory of economic growth (New Edition). Publisher: Routledge.

Litvine, D., \& Wüstenhagen, R. (2011). Helping light green consumers walk the talk, results of a behavioural intervention survey in the Swiss electricity market. Ecological Economics, 70, 462-474. https://doi.org/10.1016/j.ecolecon.2010.10.005

Loibl, C., Kraybill, D. S., \& DeMay, S. W. (2011). Accounting for the role of habit in regular saving. Journal of Economic Psychology, 32(4), 581-592. https://doi.org/10.1016/j.joep.2011.04.004

Lu, J., Yu, C. S., Liu, C., \& Yao, J. E. (2003). Technology acceptance model for wireless internet. Internet Research, Electronic Networking Applications and Policy, 13(3), 206-222. https://doi.org/10.1108/10662240310478222

Lusardi, A. (2008). Household saving behaviour: The role of financial literacy, information, and financial education programs. NBER Working Paper No. 13824, 1-43.

Lusardi, A., Keller, P., \& Keller, A. (2009). New ways to make people save: A social marketing approach. Working Paper, No. 14715, 1-38. https://doi.org/10.7208/chicago/9780226497105.003.0008

Lusardi, A., Mitchell, O. S., \& Curto, V. (2010). Financial literacy among the young. Journal of Consumer Affairs, 44(2), 358-380. https://doi.org/10.1111/j.1745-6606.2010.01173.x

Lyons, A. C., Chang, Y., \& Scherpf, E. M. (2006). Translating financial education into behaviour change for low-income populations. Financial Counseling and Planning Journal, 17(2), 27-45.

McCleary, R. (2007). Salvation, damnation and economic incentives. Journal of Contemporary Religion, 22(1), 49-74. https://doi.org/10.1080/13537900601114503

Minton, E., Kahle, L., \& Kim, C. (2015). Religion and motives for sustainable behaviors: A cross-cultural comparison and contrast. Journal of Business Research, 68(9), 1-8. https://doi.org/10.1016/j.jbusres.2015.01.003

Mokhlis, S. (2009). Relevancy and measurement of religiosity in consumer behavior research. International Business Research, 2(3), 75-84. https://doi.org/10.5539/ibr.v2n3p75

Pearlin, L. I., \& Schooler, C. (1978). The structure of coping. Journal of Health and Social Behavior, 19(1), 2-21. https://doi.org/10.2307/2136319

Phillips, W. J., \& Jang, S. (2012). Exploring seniors' casino gaming intention. Journal of Hospitality \& Tourism Research, 36(3), 312-334. https://doi.org/10.1177/1096348010388656

Ramayah, T., Noor, M. N. M., Nasurdin, A. M., \& Hasan, H. (2003). Students' choice intention of a higher learning institution: an application of the theory of reasoned action (TRA). Malaysian Management Journal, 7(1), 47-62.

Ramayah, T., Noor, M. N. M., Nasurdin, A. M., \& Sin, Q. B. (2004). The relationships between belief, attitude, subjective norm, intention, and behaviour towards infant food formula selection: the views of the Malaysian mothers. Gadjah Mada International Journal of Business, 6(3), 405-418.

Ramayah, T., Rouibah, K., Gopi, M., \& Rangel, G. J. (2009). A decomposed Theory of Reasoned Action to explain intention to use internet stock trading among Malaysian investors. Computers in Human Behaviour, 25(2), 1222-1230. https://doi.org/10.1016/j.chb.2009.06.007

Renneboog, L., \& Spaenjers, C. (2012). Religion, economic attitudes and household finance. Oxford Economic Papers, 64(1), 103-124. https://doi.org/10.1093/oep/gpr025

Rhodes, R. E., \& Courneya, K. S. (2003). Investigating multiple components of attitude, subjective norm, and perceived control: An examination of the Theory of Planned Behaviour in the exercise domain. The British Journal of Social Psychology, 42, 129-146. https://doi.org/10.1348/014466603763276162

Ruefenacht, M., Schlager, T., Maas, P., \& Puustinen, P. (2015). Drivers of long-term savings behaviour from the consumers' perspective. International Journal of Bank Marketing, 33(7), 922-943. https://doi.org/10.1108/IJBM-11-2014-0168 
Rutherford, L. G., \& DeVaney, S. (2009). Utilizing the theory of planned behaviour to understand convenience use of credit cards. Financial Counselling and Planning, 20(2), 48-63.

Ryu, S., Ho, S. H., \& Han, I. (2003). Knowledge sharing behaviour of physicians in hospitals. Journal of Expert systems with application, 25(1), 113-122. https://doi.org/10.1016/S0957-4174(03)00011-3

Sparks, B., \& Pan, G. W. (2009). Chinese outbound tourists: understanding their attitudes, constraints and use of information sources. Tourism Management, 30(4), 483-494. https://doi.org/10.1016/j.tourman.2008.10.014

Taylor, S., \& Todd, P. (1995). Decomposition and crossover effects in the theory of planned behaviour: a study of consumer adoption intentions. International Journal of Research in Marketing, 12(2), 137-156. https://doi.org/10.1016/0167-8116(94)00019-K

Tsai, C. Y. (2010). Applying the theory of planned behaviour to explore the independent travellers' behaviour. African Journal of Business Management, 4(2), 221-234.

Tsourgiannis, L., Karasavvoglou, A., Tsourgiannis, C., Florou, G., Theodosiou, T., \& Valsamidis, S. (2014). Factors affecting consumers in Greece to buy during the economic crisis period food produced domestically in Greece. Procedia Economics and Finance, 9, 439-455. https://doi.org/10.1016/S2212-5671(14)00046-X

Venkatesh, V., \& Davis, F. D. (2000). A theoretical expansion of the technology acceptance model: four longitudinal field studies. Management Science, 46(2), 186-204. https://doi.org/10.1287/mnsc.46.2.186.11926

Wang, J., \& Ritchie, B. W. (2013). Attitudes and perceptions of crisis planning among accommodation managers: Results from an Australian study. Safety Science, 52(1-2), 81-91. https://doi.org/10.1016/j.ssci.2012.02.005

Warneryd, K. E. (1996a). Personality and saving. VSB-Centre savings project progress report, No. 39, Tilburg, The Netherlands: Tilburg University, Centre for Economic Research.

Warneryd, K. E. (1996b). Saving attitudes and saving behaviour. In Roland-Levy, C. (Ed.), Proceedings of the 21th IAREP Colloquium: Social and Economic Representations (pp. 798-811). Paris: Universite Rene Descartes, Institute de Psychology.

Warneryd, K. E. (1999). The psychology of saving. A study of economic psychology. Cheltenham: Edward Elgar Publishing.

Webley, P., \& Nyhus, E. K. (2001). Life-cycle and dispositional routes into problem debt. British Journal of Psychology, 92(3), 423-446. https://doi.org/10.1348/000712601162275

Worthington, E. L., Jr., Wade, N. G., Hight, T. L., McCullough, M. E., Berry, J. T., Ripley, J. S., ... Bursley, K. H. (2003). The Religious commitment Inventory-10: Development, refinement and validation of a brief Scale for research and counselling. Journal of Counseling Psychology, 50(1), 84-96. https://doi.org/10.1037/0022-0167.50.1.84

Worthington, E. L., Jr., Wade, N. G., Hight, T. L., Ripley, J. S., McCullough, M. E., Berry, J. W., ... O'Conner, L. (2012). The Religious commitment Inventory-10 (RCI-10). Measurement Instrument database for the social science. Retrieved July 15, 2015, from www.midss.ie

Xiao, J. J., \& Wu, J. (2008). Completing debt management plans in credit counselling: An application of the theory of planned behaviour. Journal of Financial Planning and Counseling, 19(2), 29-45.

Xiao, J. J., Tang, C., Serido, J., \& Shim, S. (2011). Antecedents and consequences of risky credit behaviour among college students: Application and extension of the Theory of Planned behaviour. Journal of Public Policy \& Marketing, 30(2), 239-245. https://doi.org/10.1509/jppm.30.2.239

Yang, J. (2013). The Theory of Planned behaviour and prediction of entrepreneurial intention among Chinese undergraduates. Social Behavior and Personality, 41(3), 367-376. https://doi.org/10.2224/sbp.2013.41.3.367

Zocchi, P. (2013). Why do Italian households prefer adjustable rate mortgages?. Journal of European Real Estate Research, 6(1), 90-110. https://doi.org/10.1108/17539261311312997 